Hanna MARTYNIUK ${ }^{1}$, Nadiia MARCHENKO², Olena MONCHENKO ${ }^{3}$

DOI: https://doi.org/10.53052/9788366249868.14

\title{
ANALIZA PORÓWNAWCZA WŁAŚCIWOŚCI MASKUJĄCYCH GENERATORÓW SZUMU
}

\begin{abstract}
Streszczenie: Problem ochrony i przetwarzania informacji mowy jest jednym z problemów bezpieczeństwa informacji. W niniejszej pracy autorzy postanowili zbadać dokładnie generatory szumu, które są instalowane w pomieszczeniu w celu uniemożliwienia odbioru informacji mowy. Do tej pory opracowano wiele różnych generatorów szumu. Różne generatory zostały zaprojektowane w celu rozwiązania szerokiego zakresu problemów teoretycznych i praktycznych w różnych dziedzinach nauki i techniki. Autorzy postanowili poznać właściwości maskujące generatorów szumu. Do tego zadania wykorzystano różne generatory szumu: symulowane i fizyczne generatory szumów białego i różowego. W pracy przedstawiono numeryczne charakterystyki jakości generatorów, a także sformułowano wniosek o celowości stosowania generatorów do maskowania mowy człowieka.
\end{abstract}

Słowa kluczowe: generator szumu, szum biały, szum różowy, mowa człowieka, analiza.

\section{COMPARATIVE ANALYSIS OF MASKING PROPERTIES OF NOISE GENERATORS}

\begin{abstract}
The problem of protecting and processing speech information is one of the problems of information security. In this work, the authors decided to study exactly the noise generators that are installed in the room to prevent the receipt of speech information. A large number of different noise generators have been developed to date. Various generators are designed to solve a wide range of theoretical and practical problems in various branches of science and technology. The authors decided to understand the masking properties of noise generators. For the task, various noise generators were used: simulated and physical generators of white and pink noise. The paper presents the numerical characteristics of the quality of the generators, and also makes a conclusion about the advisability of using generators for masking human speech.
\end{abstract}

Keywords: Noise Generator, White Noise, Pink Noise, Human Speech, Analysis.

\footnotetext{
${ }^{1} \mathrm{PhD}$, National Aviation University, Information Security Department, ganna.martyniuk@gmail.com

$2 \mathrm{PhD}$, National Aviation University, Department of Computerized control systems, nadmar@i.ua

${ }^{3} \mathrm{PhD}$, National Aviation University, Biocibernetics and aerospace medicine Department, monchenko_olena@ukr.net
} 


\section{Introduction}

The problem of protecting and processing speech information is one of the problems of information security. The current state of the problem of protecting speech information is characterized by the constant expansion of the arsenal of means of secret interception of acoustic (speech) signals, the technical characteristics and methods of which are constantly improving. The development and study of various methods of processing and protection of speech information, as well as the definition of intelligibility of speech messages as the main indicator of their security are devoted to many works by foreign and domestic authors [1-10].

In accordance with the general information security methods, the following methods are used to protect against eavesdropping [1]:

- $\quad$ structural hiding, that include:

- encryption of semantic speech information in functional communication channels;

- technical closure of electrical and radio signals in telephone communication channels;

- misinformation;

- energy hiding by:

- $\quad$ soundproofing the acoustic signal;

- $\quad$ sound absorption of acoustic waves;

- $\quad$ noise of the room with other sounds (noise, interference), providing masking of acoustic signals;

- $\quad$ detection, localization and withdrawal of embedded devices.

In this work, the authors decided to study exactly the noise generators that are installed in the room to prevent the receipt of speech information.

\section{Publications analysis. Problem statement}

The protection of acoustic (speech) information is one of the most important tasks in the general complex of measures to ensure the information security of an object or institution and is carried out using passive and active methods. The papers [2-5] present the use of a relatively new method of masking speech signals - noise "speechlike" interference. The papers [6-7] indicate various types of noise signals that can mask a speech signal. And only papers [8-10] give us explanation about using physical or computer noise generator, that organizations can used for noising the room.

Authors thought, that today is not enough information about new noise generators and information about some masking properties of these. In this regard, the work will provide information on the characteristics of noise generators that work in rooms where it is necessary to protect the conversation between the interlocutors.

\section{Proposed methodology}

One of the most common methods of information protection is to create a noise acoustic interference that hides an informative signal, while the ratio of the magnitude 
of the noise signal / the magnitude of the informative signal should ensure reliable hiding of the informative signal or reduce its intelligibility to sufficient limits.

The volume of a sound perceived by a person depends not only on its own intensity, but also on other sounds acting simultaneously on the eardrum of the ear [1]. Due to the psychophysiological characteristics of human perception of sound, the intensity of masking sounds is asymmetric. This is because the masking sound has relatively little effect on the tones of the masked sound below its natural frequency, but makes it very difficult to perceive the higher sounds. Therefore, low-frequency acoustic noise signals are effective for masking acoustic signals.

It should be noted that acoustic noise provides effective protection of information in it if the acoustic generator is located closer to the attacker's acoustic receiver than the information source. For example, when eavesdropping is possible through a door or an open window, it is advisable to place the acoustic generator near the door or on the window sill. If the location of an intruder's acoustic receiver is unknown, for example, an embedded device, then placing an acoustic generator between speaking people, as some companies recommend, does not guarantee reliable information protection. In addition, increasing the noise level forces the interlocutors to speak louder, which creates discomfort and reduces the effect of noise.

Popular indoor noise generators today are white and pink noise generators. White Noise contains the same total amount of energy within each frequency. Pink Noise contains the same total amount of energy within each octave. Both white and pink noise are considered broadband noises. Both of them are made of all frequencies that are audible to humans, so all frequencies anywhere between 20 and 20000 hertz. But the way their signal power is distributed among all frequencies radically differs.

For understanding masking properties, the authors propose for consideration 2 types of generators: a physical white noise generator and a physical pink noise generator. As a signal that needs to be masked, a dialogue of two women is used for a duration of 20 seconds.

To carry out a computer simulation experiment, it is proposed to evaluate the characteristics of such signals: a speech signal, generator signals, a sequence of a speech signal and generator signals. For each type of signal, it is recommended to estimate the mean, variance and standard deviation. In addition, it is recommended to construct an auto-correlation function, a histogram, and a spectral characteristic of the received signals. Such calculations will allow evaluating the quality of signal masking by noise generators from a mathematical point of view.

\subsection{Characteristics of an acoustic speech signal}

For clarity, the statistical characteristics of the acoustic speech signal are presented in Table 1.

Table 1.Characteristics of an acoustic speech signal

\begin{tabular}{|c|c|c|c|}
\hline sampling frequency & mean & variance & standard deviation \\
\hline $11025 \mathrm{~Hz}$ & $-1.35 \cdot 10^{-5} \mathrm{~V}$ & 0.0041 & 0.0638 \\
\hline
\end{tabular}

In fig. 1-3 shows the graphical characteristics for this signal. 


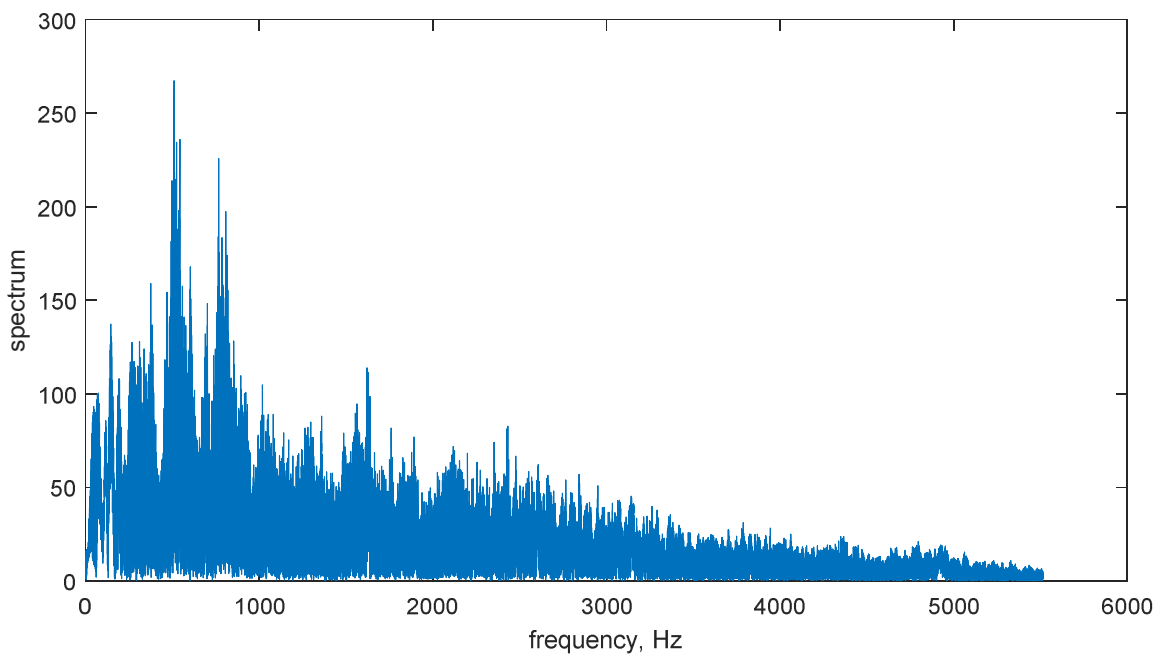

Figure 1. Speech signal spectrum

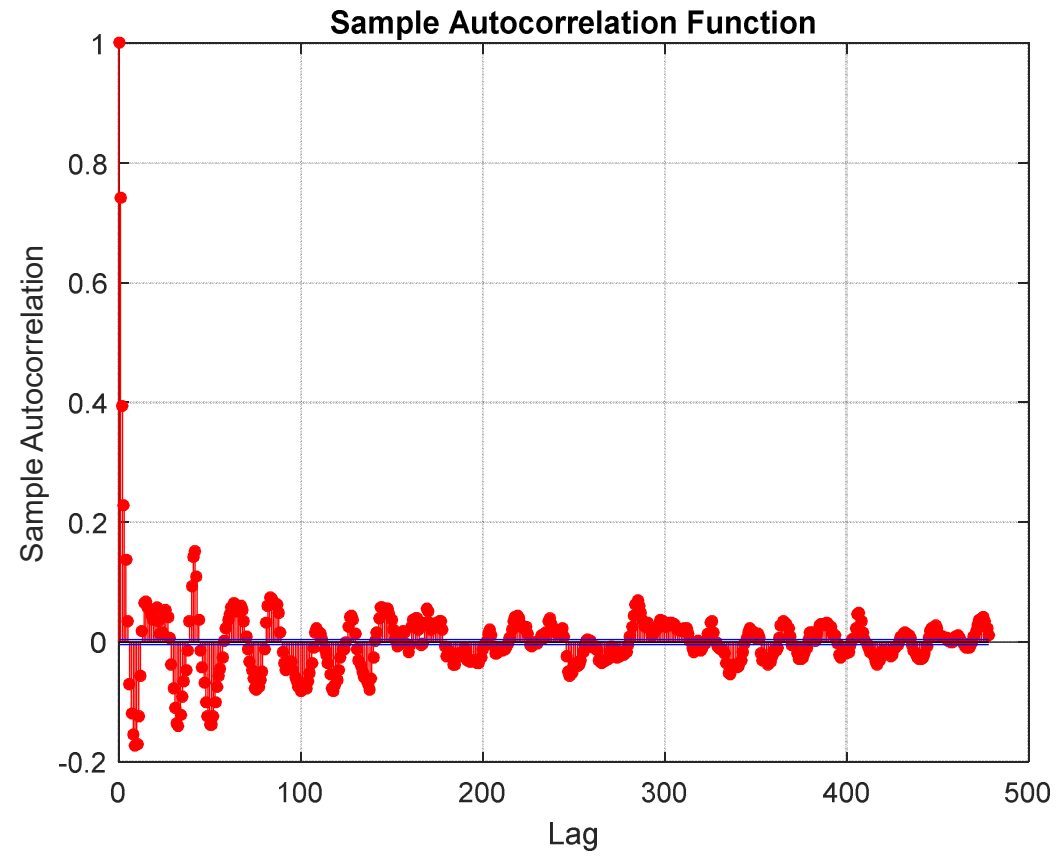

Figure 2. Autocorrelation function of speech signal 


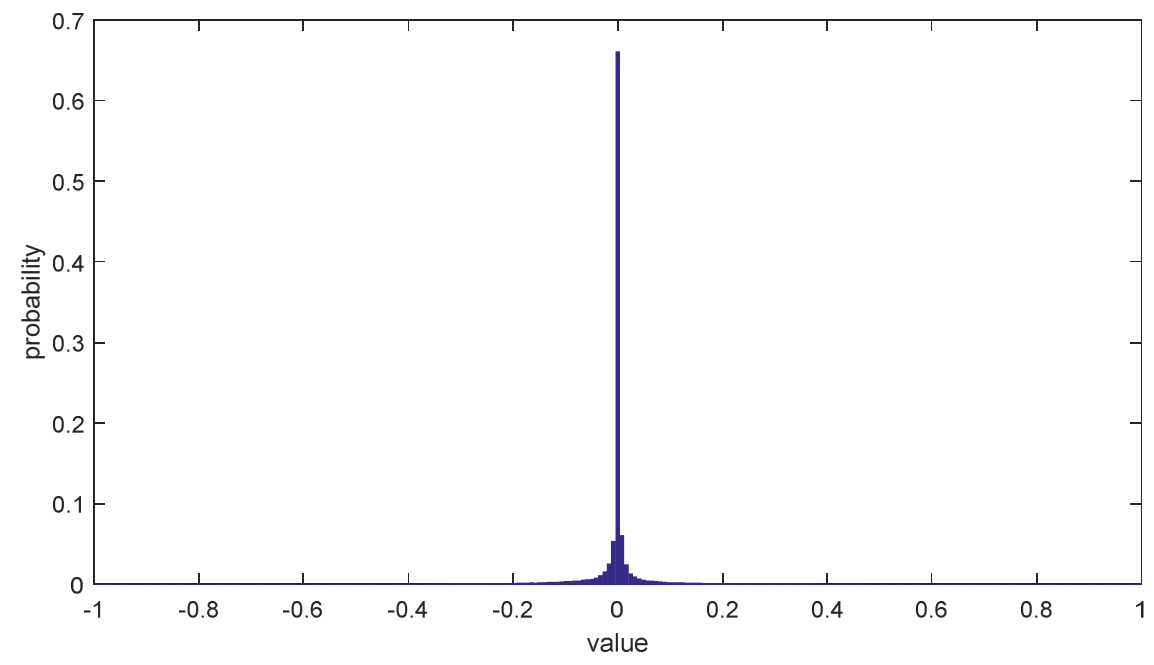

Figure 3. Histogram of speech signal

\subsection{Characteristics of noise generators}

The statistical characteristics of the acoustic speech signal are presented in Table 2.

Table 2. Characteristics of a noise generator signals

\begin{tabular}{|c|c|c|c|c|}
\hline $\begin{array}{c}\text { Type of } \\
\text { generator }\end{array}$ & $\begin{array}{c}\text { sampling } \\
\text { frequency }\end{array}$ & mean & variance & $\begin{array}{c}\text { standard } \\
\text { deviation }\end{array}$ \\
\hline White noise & $44100 \mathrm{~Hz}$ & $1.45 \cdot 10^{-5} \mathrm{~V}$ & 0.2130 & 0.4615 \\
\hline Pink noise & $44100 \mathrm{~Hz}$ & 0.0157 & 0.0318 & 0.1784 \\
\hline
\end{tabular}

In fig. 4-9 shows the graphical characteristics for this signal. 


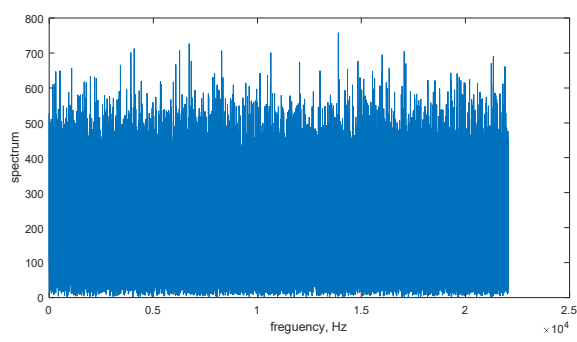

Figure 4. White noise signal spectrum

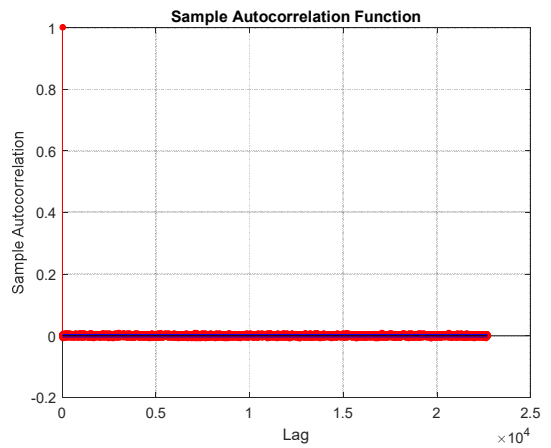

Figure 5. Autocorrelation function of white noise signal

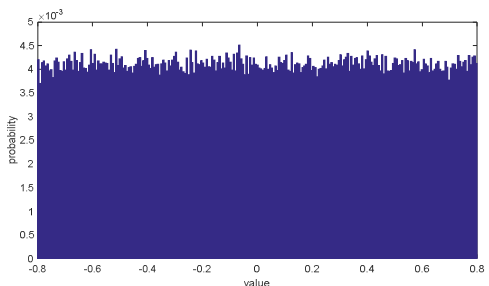

Figure 6. Histogram of white noise signal

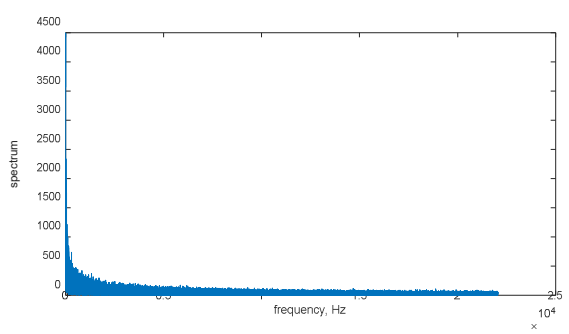

Figure 7. Pink noise signal spectrum

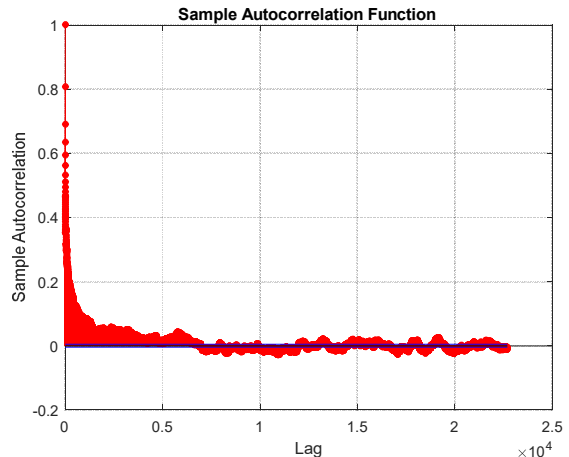

Figure 8. Autocorrelation function of pink noise signal

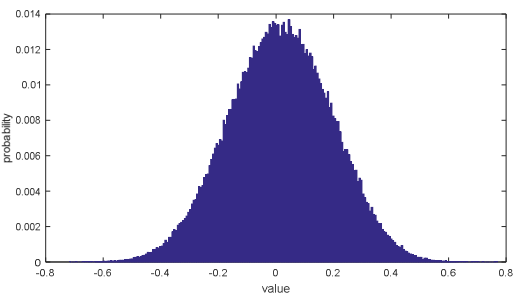

Figure 9. Histogram of pink noise signal

The graphs and numerical values obtained above clearly illustrate the behavior of the generators for the selected types of noise signals.

\subsection{Characteristics of noise generators and speech signal}

The statistical characteristics of the acoustic speech signal are presented in Table 3.

Table 3. Characteristics of a noise generator and speech signals

\begin{tabular}{|c|c|c|c|}
\hline $\begin{array}{c}\text { Type of } \\
\text { generator }\end{array}$ & mean & variance & $\begin{array}{c}\text { standard } \\
\text { deviation }\end{array}$ \\
\hline White noise & $9.92 \cdot 10^{-7} \mathrm{~V}$ & 0.2170 & 0.4658 \\
\hline Pink noise & 0.0157 & 0.0359 & 0.1894 \\
\hline
\end{tabular}


In fig. 10-13 shows the graphical characteristics for this signal.

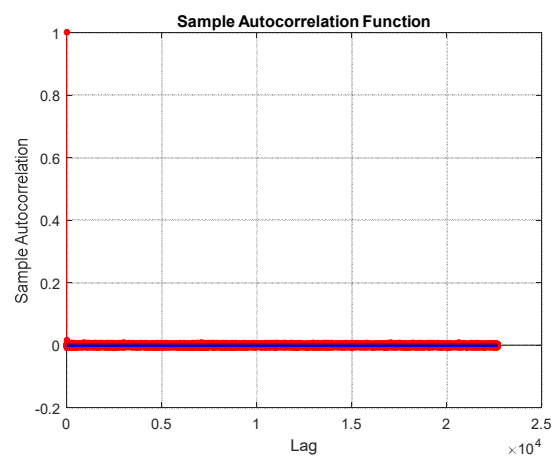

Figure 10. Autocorrelation function of white noise and speech signals

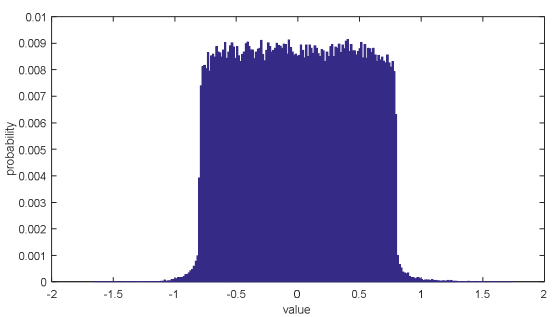

Figure 11. Histogram of white noise and speech signals

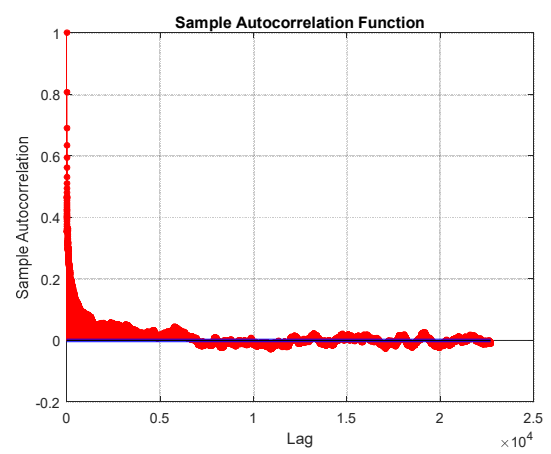

Figure 12. Autocorrelation function of white noise and speech signals

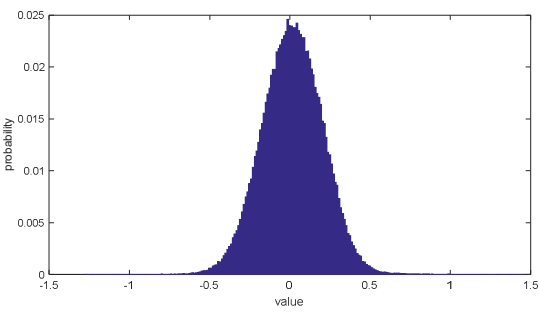

Figure 13. Histogram of white noise and speech signals

\section{Results}

Analyzing the numerical data obtained in tables 1-3, authors can conclude that the presence of a speech signal introduces minor changes in the numerical data of the signal. But such changes are so minor that they can be neglected.

At the same time, examining the graphical data obtained in Fig. 1-13, the changes in the histogram of the white noise generator are clearly visible. This makes it possible for an attacker to understand that there is a speech component in the audio signal that was filmed. However, when considering the graphical characteristics of the pink noise generator, it will be quite difficult for an attacker to make out the presence or absence of a useful speech message in the received signal.

\section{Conclusions}

This work is devoted to evaluating the characteristics of signals at the output of noise generators. Presented numerical and graphical characteristics for white and pink noise 
generators. A comparative analysis of the characteristics of noise signals in the presence of a useful speech message is made.

\section{REFERENCES}

1. HOREV A., MAKAZOV YU.: Evaluation of the effectiveness of the vibroacoustic masking system. URL: http://www.analitika.info.

2. HOREV A., TSAREV H.: Method and algorithm for formation of speech-like interference. "Proceedings of Voronezh State University. Series: Systems Analysis and Information Technologies", Volume 1 (2017): 57-67.

3. ZHANG J., ABHAYAPALA T. D., ZHANG W., SAMARASINGHE P. N., JIANG S.: Active Noise Control Over Space: A Wave Domain Approach, in IEEE/ACM Transactions on Audio, Speech, and Language Processing, vol. 26, no. 4, pp. 774786, April 2018, doi: 10.1109/TASLP.2018.2795756.

4. KWON H., KIM Y., YOON H. CHOI D.: Selective Audio Adversarial Example in Evasion Attack on Speech Recognition System, in IEEE Transactions on Information Forensics and Security, vol. 15, pp. 526-538, 2020, doi: 10.1109/TIFS.2019.2925452.

5. CARLINI N., WAGNER D.: Audio Adversarial Examples: Targeted Attacks on Speech-to-Text, 2018 IEEE Security and Privacy Workshops (SPW), 2018, pp. 1-7, doi: 10.1109/SPW.2018.00009.

6. ALZANTOT M., BALAJI B., SRIVASTAVA M.: Did you hear that? Adversarial Examples Against Automatic Speech Recognition, in NIPS 2017 Machine Deception workshop.

7. Understanding the Difference Between White Noise, Pink Noise, and Sound Masking. URL: https://www.softdb.com/what-is-white-noise/

8. BARABANOV N. A., VENEDIKTOV YU. I., IVANOV D. A.: A study on noise generators, in: 22nd International Scientific and Practical Conference "Modern Information and Electronic Technologies", 2018, pp. 70-71.

9. Protection of speech information. URL: http://www.confident.org.ua/index.php/stati-po-teme/198-zashchita-rechevojinformatsii.html

10. BEZSHTANKO V., BONDARENKO V., GAVRYLENKO O., YEVSEIEV S., IVANCHENKO S., KAZAKOVA N., KOROLEV R., MAZOR S., ROMANENKO V., FRAZE-FRAZENKO O.: Enhancement of productivity of random sequences generation for information protection systems in: Eastern-European Journal of Enterprise Technologies. Vol. 4 (9), pp. 50-60 